\title{
Swedenborg's Treatise on Copper
}

$\mathrm{T}$ HE circumstances in which a translation of Swedenborg's historic "Treatise on Copper" has become available to the public are indicated in a preface to the edition recently published*, written by Mr. Fullman, editor and information officer of the British Non-Ferrous Metals Research Association. He writes:

"In 1734 Emanuel Swedenborg, the Swedish Scientist, Philosopher and Mystic, published the three volumes of his Latin Treatise "Opera Philosophica et Mineralia'. The first volume contains a mechanical and geometrical theory of the origin of things: a translation was published by the Rev. Augustus Clissold under the title "The Principia or the First Principles of Natural Things', (London 1846. 2 volumes). The second volume deals with iron and steel and has been translated into French and Swedish : a long review of the Swedish translation by Harald Carlborg appeared in 'The New Philosophy', April 1926, Vol. 29, No. 2, pp. 33-59. The third volume is concerned with copper: it is commonly known as The Treatise on Copper, or 'de Cupro', since the Latin title commences 'Regnum Subterraneum sive Minerale de Cupro et Orichalco'."

Some years ago, Mr. Fullman had occasion to check various references to the "Treatise on Copper" and, not finding any version of the book other than the original Latin, called on the Rev. J. R. Presland, librarian of the Swedenborg Society at Swedenborg House, to see if he could assist him. From him he learned that no translation of the "Treatise" had been published, but that the Society had a manuscript translation in its strong room, and also that Mr. L. P. Ford had approached Mr. A. H. Searle with a view to the translation of the original Latin, and that the work was done at Mr. Ford's expense in 1901. He offered the translation to the Council (then Committee) of the Swedenborg Society "on the condition of its undertaking to publish the work". This offer the Committee found itself unable to accept. At a meeting, held a year later, a request was received from Mr. Ford, "to preserve the English translation of Swedenborg's treatise on Copper by depositing it in their strong room". This request the Committee granted and the manuscript was shortly afterwards placed in the strong room at

* British Non-Ferrous Metals Research Association. Miscellaneous Publication No 333. Swedenborg's Treatise on Copper (Opera Philosopion No Philosophica et Mineralia, Vol. 3). Translated into English by Arthur Hodson Searle, Section 1 : Being Chapters I-XIX of Part I of Original. Pp. Xviii +180. Section 2: Being Chapters XX-XLIX of Part I of Original. Pp. iii +181-348. Section 3: Being Chapters L-LIII of Part 1 : Part 2 (Chapters I-IV); and Part 3 (Chapters I-XII) of Ferrous Metals Research Association, 1938.) 258.; to Members, 158.
No. 1, Bloomsbury Street, London, from which it was transferred to Swedenborg House, Hart Street, W.C.l, when the Society moved there in 1925.

The translator, Authur Hodson Searle, was born in 1839 and died in 1914 . When he was about four years old, he suffered an illness which deprived him completely of his hearing, and consequently, for a time, of speech. He was taught the finger alphabet and lip reading, and thus learned to converse, although in a somewhat muffled voice. In spite of these physical disabilities, he became an excellent Hebrew and Latin scholar. He was not a metallurgist, being in fact occupied as an artist in reproducing for the engraver plates of conchological specimens. "All in all," as Mr. Fullman writes, "his preparation of this translation is a remarkable achievement and no reader of it can fail to be impressed by its quality."

The British Non-Ferrous Metals Research Association has recently reproduced the translation in mimeograph form in three volumes, and the present reproduction makes this work, which is of great interest to metallurgists and others, readily accessible at a reasonable figure.

Swedenborg divided his "Treatise" into three parts. The first, which constitutes the great bulk of the work and is the most important, deals with the methods of smelting copper from its ores, and the refining of copper as produced in Sweden, Norway, Russia, England, Spain, Hungary, Germany, Austria and elsewhere, with notes on the same subject from treatises by various authors. The latter part of this volume contains an account of methods used for the separation of silver from copper and a discussion of brass and processes for its production. The second part commences with an account of the nature of various copper ores and their occurrence throughout the world, and then deals with the assaying of copper ore, including assaying for silver. The third and last part deals with miscellaneous matters including the production of various compounds of copper, the specific gravity of the metal and its increase of weight on oxidation.

Pride of place in the first part is given to an account of the method of roasting, smelting and refining of Fahlun ore. This was one of the greatest copper mines in the world. The author states that, at the time of publication of his book, the great mine was still unexhausted though having been continuously worked for a period of a thousand years. At the height of its fame it yielded $60,000 \mathrm{cwt}$. of copper yearly, so that, to use his words, "All its foundations, doors, grottoes, 
walls, porticoes, halls and columns were thrown open to their fullest extent, the ore glittering on all sides with a ruddy glow and almost blinding the eyes with rays of golden colour, so that the guests now coming from Fahlun seemed to be, as it were, introduced into the presence of Venus herself, sitting as a bride or newly-wedded wife in her most splendid decorated bridal chamber, ready to receive and welcome them most joyfully".

The extraction of copper from its ores, mainly sulphide ores, containing iron, usually with some arsenic and antimony, was a long and laborious process. Briefly, it was as follows: First there was a calcination to drive off volatiles, wood fuel being used. This was followed by fusion and smelting, in which the fuel was crushed coal, the air being blown in from a blast pipe about three inches in diameter. In this way a copper 'stone' was produced and collected in the fore-hearth, which was tapped every two hours. This stone was of an intense blood-red colour and flowed very slowly. Then followed a second calcination which consisted of six successive treatments in a 'burning fire'. The gradual removal of the volatiles took place, with accordingly an enrichment of copper. This calcination lasted about five weeks. Then came a second smelting, which occupied a further week, in which further quantities of iron were slagged off, and the cupreous product was tapped from time to time. This was known as coarse or black copper. These furnaces were situated within a mile of the mine, and there were about a hundred and thirty of them. Next followed the refining of the coarse copper at Afwedstad in Sweden, and the final stage consisted in the smelting of this so that it could be beaten out into laminæ or plates. The total period required was between seven and eight weeks and the maximum annual production was about 2,000 tons, corresponding to a weekly output of not more than 40 tons. When it is considered that the daily production of a modern copper works is of the order of 300 tons of refined metal, it will be realized that considerable advances have been made in the smelting and refining of copper in the last two hundred years.

The British Non-Ferrous Metals Research Association is to be commended for its public spirit in rendering available a treatise which gives so much information about the metallurgy of copper in the late seventeenth and early eighteenth centuries.

H. C. H. C.

\title{
Oceanography and the Fluctuations in the Abundance of Marine Animals*
}

\author{
By Dr. Stanley Kemp, F.R.S.
}

$I_{\mathrm{w}}^{\mathrm{T}}$ is interesting to note that the observations we have of salinity and temperature cannot be correlated with the biological data. For many years past, Dr. H. W. Harvey has followed the temperature and salinity changes at the western end of the Channel, and during the period since 1924 he has found that the most conspicuous movements were large incursions of low-salinity water in May 1928 and in March and April 1936, while in 1932,1933 and 1934 (especially in 1933) patches of water with unusually high salinity moved eastwards up the Channel. So far as can be seen, these movements show no correspondence with the marked biological changes which have occurred: it is in the phosphate data only that a correlation can be found.

In the year 1921 there was an exceptional influx of Atlantic water, which filled the Channel and flooded into the North Sea. Salinity and temperature were much above normal and numbers of unusual planktonic organisms of Atlantic origin were found in the North Sea. Recent experience

(Continued from p. 779.) at Plymouth might lead one to think that such an influx as this would bring benefit to the herring fisheries, but actually it was just the reverse, for at Plymouth and in the North Sea, at Lowestoft, Yarmouth, Grimsby and North Shields, the herring fishery was much below normal.

It thus appears that incursions of Atlantic water into the Channel may bring advantage to the biology of the area or may be detrimental, that no obvious connexion between the biological data and temperature and salinity is noticeable, and that so far as we can at present see, the only correlation that can be established is with phosphate. The explanation lies, I believe, in our very considerable ignorance of the constitution and origin of the water-masses which from time to time enter the Channel.

There is evidently more than one way in which an influx of Atlantic water may be advantageous. It may, in the first place, bring water with a high content of phosphate and other nutrient salts which will eventually yield an abundant plankton. Or, secondly, though deficient in phosphate, it 